\title{
動物遺体をいかに解剖するか
}

\author{
佐々木基樹 \\ 帯広畜産大学畜産学部獣医学科基礎獣医学講座解剖学教室 $=080-8555$ 帯広市稲田町西 2 線 11 番地

\section{How Do We Have to Dissect Animal Carcasses ?}

Motoki SASAKI

Laboratory of Anatomy, Department of Basic Veterinary Science, Obihiro University of Agriculture and Veterinary Medicine, Inada-cho, Nishi 2-11, Obihiro 080-8555, Japan

\begin{abstract}
Many carcasses of animals have been collected by Laboratory of Anatomy, Obihiro University of Agriculture and Veterinary Medicine via many routes and used for research and /or education. The sources of the carcasses of wild animals were due to A: dead bodies of unknown cause under wild environment, B: road kill, C: captured individuals by hunting, harmful wildlife control, scientific research program and bycatch, and D: dead bodies donated from zoological parks and aquariums. It is thought that the data and specimens acquired from the carcasses of wild animals need to be positively introduced into the education of veterinary medicine for the enriched contents of zoo and wildlife medicine and the bringing up of veterinarian with rich knowledge. It is desirable that animal carcasses are extensively utilized for social and school educations and researches, and interdependently used among educational and research facilities
\end{abstract}

Key words: animal carcass, anatomy, social education, school education

Jpn. J.Zoo. Wildl. Med. 12(1): 1-13, 2007

\section{序論}

脊椎動物における系統解剖学的および比較解剖学的報告はこ れまでに多数なされている[1-10]。獣医学領域においても比 較解剖書や個々の家畜動物における解剖書が多数出版されてい る[11-26]。また, ヒトや家畜以外の動物においても詳細で体 系的な解剖書が報告されている [27-30]。広義の解剖学を, 狭 義の解剖学, 組織学, そして発生学に区分すると, 筋, 骨格, 神経, 血管などを形態的に解析する狭義の解剖学は古典的な学 問と考えられがちである。しかし, ヒトや家畜以外の動物では, その形態的特徵が必ずしも十分理解されているわけではない。 ましてや組織学や発生学分野に至っては, それら動物達にはま だまだ多くの情報が眠っているものと思われる。しかし, 家畜 以外の動物, 特に動物園や水族館に飼育されているような希少 動物種を解剖学的に解析しようとする場合には, 当然ではある がそのほとんどがすでに死亡した遺体であることを留意してお
かなくてはならない。このような動物の遺体を目の前にしたと き, いかにその原石にメスを入れ, 価值のある, 光り輝く美し い宝石に削り磨き上げていくかという難題を必ず克服しなくて はならない。今回, 带広畜産大学の解剖学教室における動物遺 体の収集と利用の現状を簡単にではあるが説明できればと考え ている。

\section{遺体の収集と利用}

帯広畜産大学獣医学科の解剖学教室では動物の遺体を積極的 に収集し，さまざまな目的のために保管している。動物の遺体 は，主に図１に示すような経路によって大学に集められてく る。この中で野生動物に関しては，A：死因不明の野生下死亡 個体, B : 交通事故個体, $\mathrm{C}$ : 狩猟, 有害鳥獣駆除, 学術調查 捕獲, 混獲といった捕獲個体, そして, D : 動物園や水族館か ら提供して頂く死亡飼育動物，の遺体が対象となる。

死因不明の野生下死亡個体では，鳥類ではエゾフクロウ 


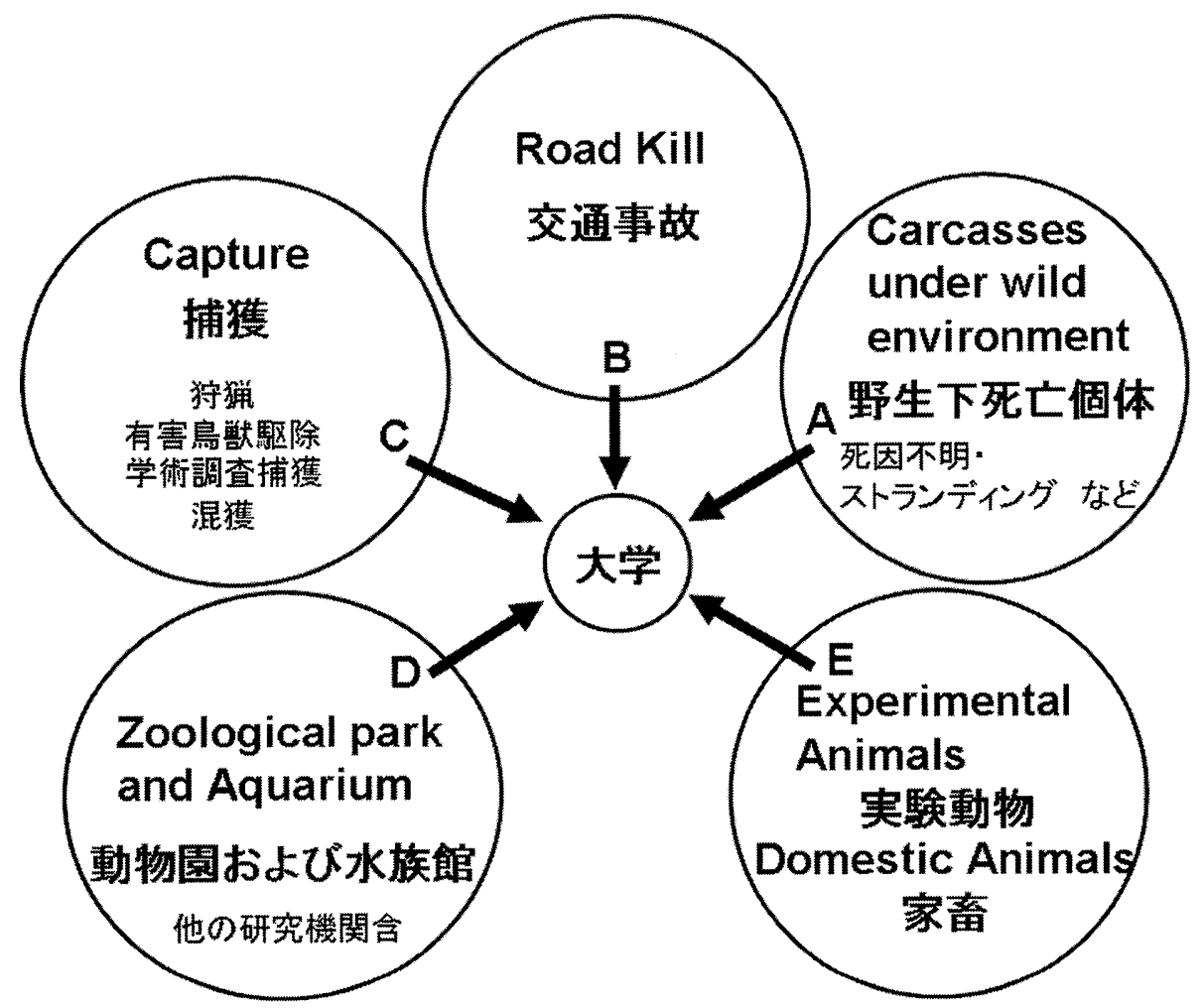

図 1 動物遺体の収集経路

(Strix uralensis coreensis : Hokkaido Ural owl), オオハクチョ ウ (Cygnus cygnus : whooper swan), ハシブトガラス (Corvus macrorhynchos : jungle crow) などが収集されて冷凍保管 されている（図 2)。これら死亡個体の推測される死因とし ては，自然死，病死，そして感電死など交通事故以外の事 故死などが考えられる。今後エゾフクロウの羽の微細構造 を同じく北海道に生息しているエゾシマフクロウ（Ketupa blakistoni：Blakiston's fish owl）の羽の微細構造と比較でき ればと考えている。さらに，哺乳類では，オオアシトガリ ネズミ (Sorex unguiculatus : long-clawed shrew), エゾシカ (Cervus nippon yesoensis : Hokkaido sika deer)，エゾタヌキ (Nyctereutes procyonides albus : Hokkaido raccoon dog)など の遺体が収集されている（図 3)。多くの場合すでに白骨化した 状態で収集されるが，外部形態を残した個体の場合にはその鮮 度によって 10\%燐酸緩衝ホルマリンや 70\%エタノールによっ て固定している。

さらに，海岸にはストランディング (stranding) といって 多くの生きた海生哺乳類 (live stranding) やその遺体 (dead stranding) が漂着することがある。これらの海生哺乳類の遺体 も許可申請を整えて積極的に収集し，さらに，ストランディ
ングデータベースの充実にも努めていければと考えている。図 4 に示された骨標本は, 以前から当解剖学教室に収蔵されてい る鯨類の頭蓋 (cranium), 頸椎 (cervical vertebra), そして腰椎 (lumber vertebra) である。これらの標本は現在, 他の骨標本 とともに大学, 大学院での講義や中学, 高校での出張授業な どの学校教育 (school education), そして市民講座などの社会 教育 (social education) に扔て大きな効果をもたらしている (図 5)。

次に，交通事故による動物遺体収集に関して記述する。現 在, 交通事故によって死亡したエゾシカ, エゾタヌキ, キタ キツネ (Vulpes vulpes schrencki : red fox), エゾリス (Sciurus vulgaris orientis : red squirrel), そしてイエネコ（ノネコ) (Felis catus：domestic cat）などの遺体が本研究室に収容されてく る。ここで注意すべきことは，北海道のキタキツネでは，人獣 共通感染症 (zoonosis) を引き起こす多胞条虫（Echinococcus multilocularis），いわゆるエキノコッカスの感染率が高いとい うことである。また，タヌキやネコにもこのエキノコックス の感染が確認されている。これら終宿主の動物の腸内に寄生 するエキノコックスの虫卵を中間宿主になりうるヒトが経口摂 取すると肝臓や脳などに重篤な症状を引き起すことが知られて 

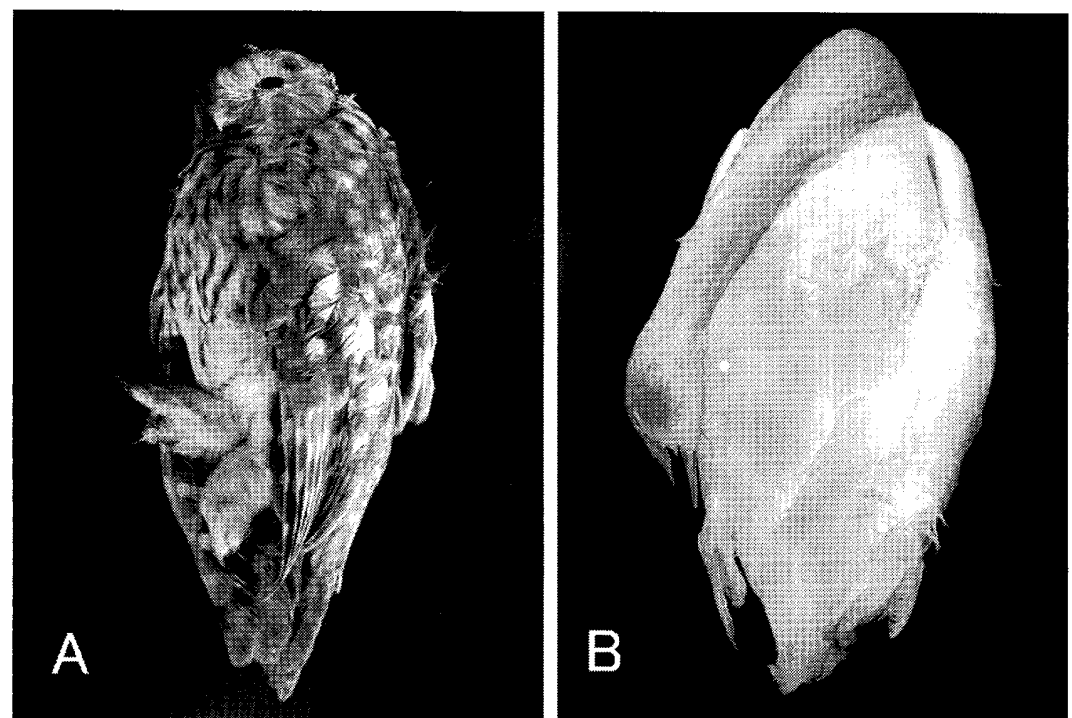

図 2 死因不明の野生下鳥類死亡個体

A：エゾフクロウ, B : オオハクチョウ。

おり，これらの動物の解剖にあたっては細心の注意が必要であ る。我々の研究室では, キツネやタヌキの遺体を解剖する際に はー 80ㄷのディープフリーザーに扎いて 10 日間一旦凍結す ることによってエキノコックスの虫卵を完全に破壊し，その後 -10ㄷ下で冷凍保管している（図 6） [31,32]。この超低温処 理を行えば実際の解剖での感染の危険性は少なくなると思われ るが，念を入れて専用ガウン，マスク，グローブを解剖時には
必ず着用するようにしている（図 7）。

次に, 捕獲による遺体の収集に関して述べていきたい。前述 したように, 狩猟, 有害鳥獣駆除, 学術調查捕獲, そして混獲 などによって野生動物が捕獲され，そして本大学に収容されて くる。有害鳥獣駆除での野生動物の捕獲方法には幾つか方法が あるが，はこわなや銃による捕獲が一般的である(図 8)。例え ば，有害鳥獣駆除によって捕獲され大学に運ばれてきたエゾシ

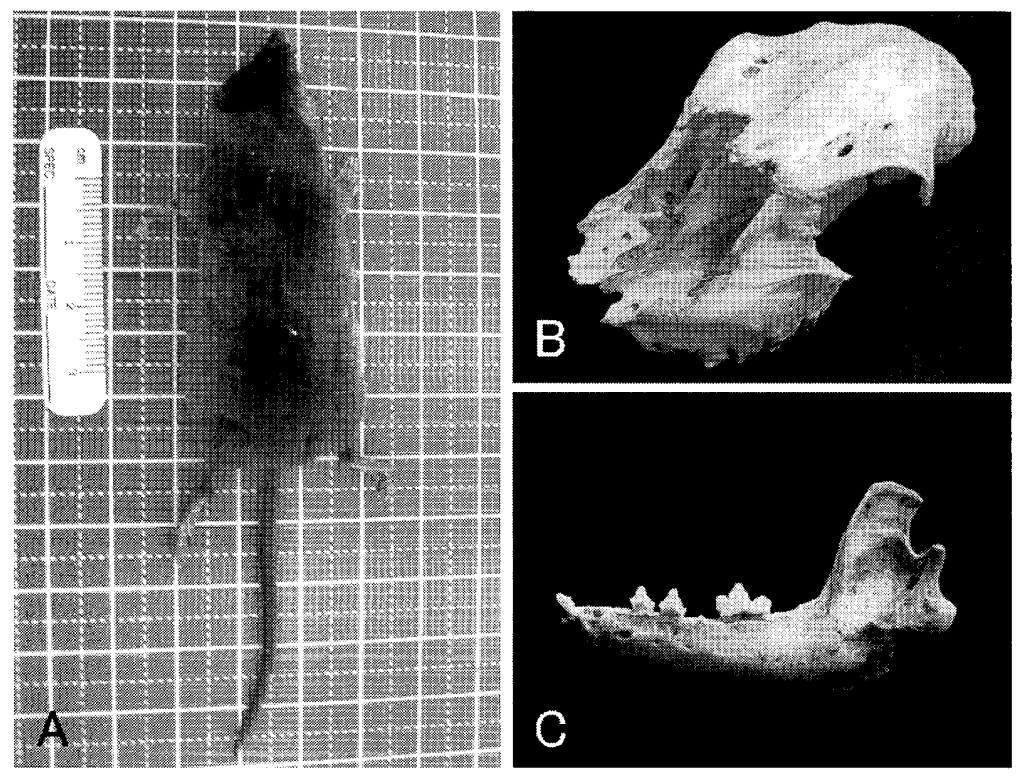

図 3 死因不明の野生下哺乳類死亡個体

$\mathrm{A}$ ：オオアシトガリネズミ，B：エゾシカ頭蓋，C：エゾタヌキ下顎骨。 

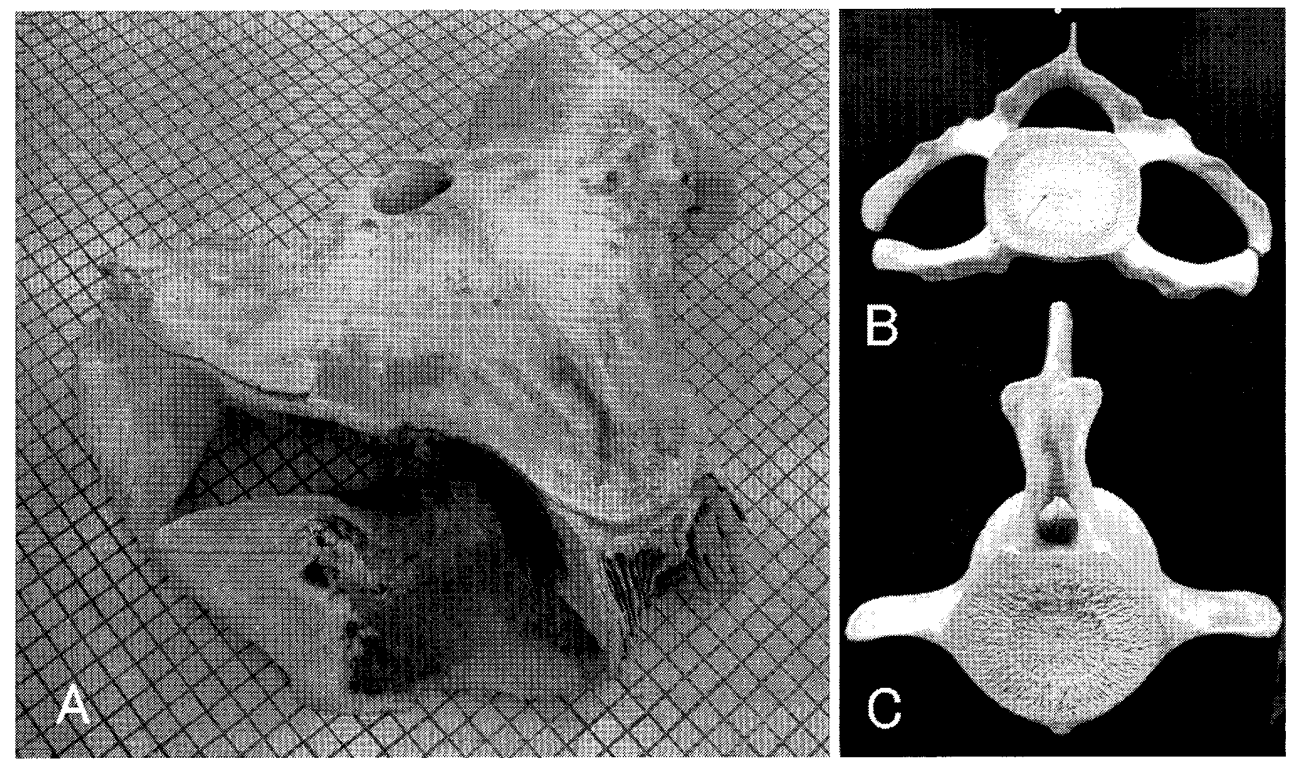

図 4 鯨類骨標本

$\mathrm{A}$ : 頭蓋, B : 頸椎, $\mathrm{C}$ : 腰椎。

力は，健体解剖室において随時解剖され，研究材料としてさま ざまな臓器や器官が採材されている（図 9)。エゾシカの場合は 有害駆除以外にも狩猟によっても遺体は入手されて同様に解剖 されている。組織を採材した後の遺体は，筋の解析のために凍 結保存している。また，最終的にはガス釜によって煮骨して骨 標本を作製している。このようにして作製された骨標本は，標 本の恒久的蓄積という観点から少しずつでも博物館等の施設に 提供していければと考えている。
北海道沿岸には，ゼニガタアザラシ (Phoca vitulina : harbor seal), ゴマフアザラシ (Phoca largha : spotted seal), クラカケ アザラシ (Histriophoca fasiata : ribbon seal), アゴヒグアザラ シ (Erignathus barbatus : bearded seal) といった鱪脚類が生 息している。また北海道沿岸はサケ，マスなどの優良な漁場と なって扔り，これらアザラシが誤って定置網に捕獲されてしま ういわゆる混獲がしばしば起こっている。これまでに定置網で 混獲され死亡したゼニガタアザラシやゴマフアザラシが，エゾ
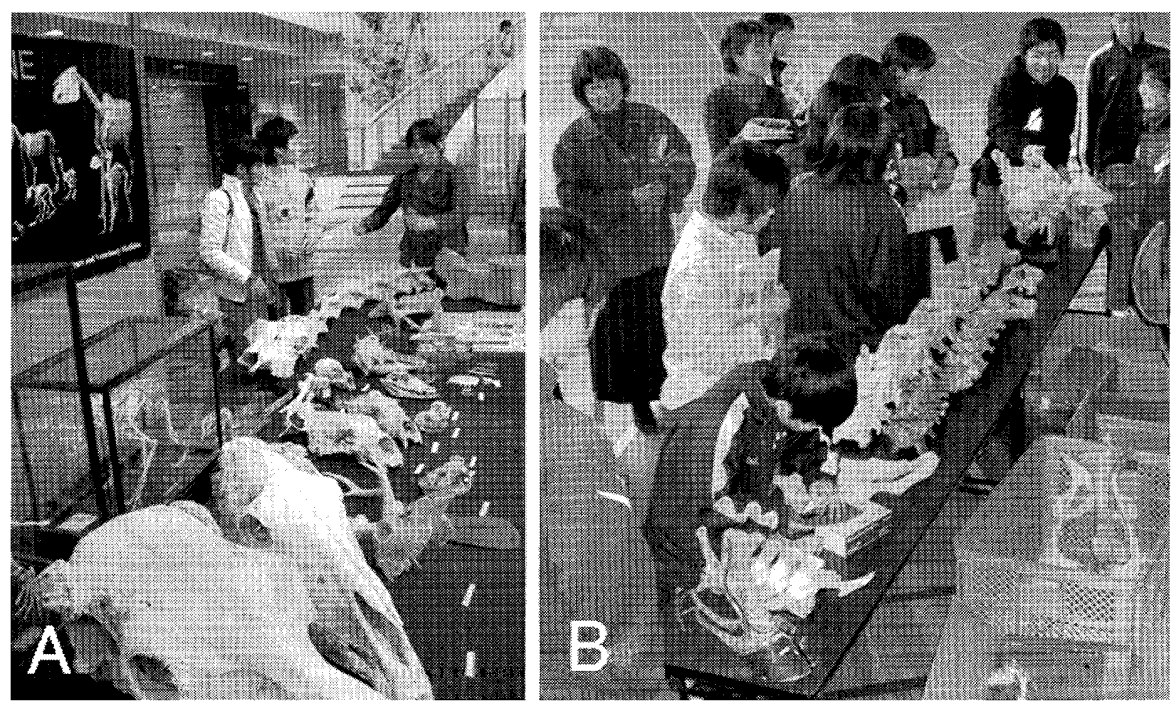

図 5 社会教育および学校教育における骨標本の利用 $A ：$ 市民公開講座での展示，B：中学校出張授業。 

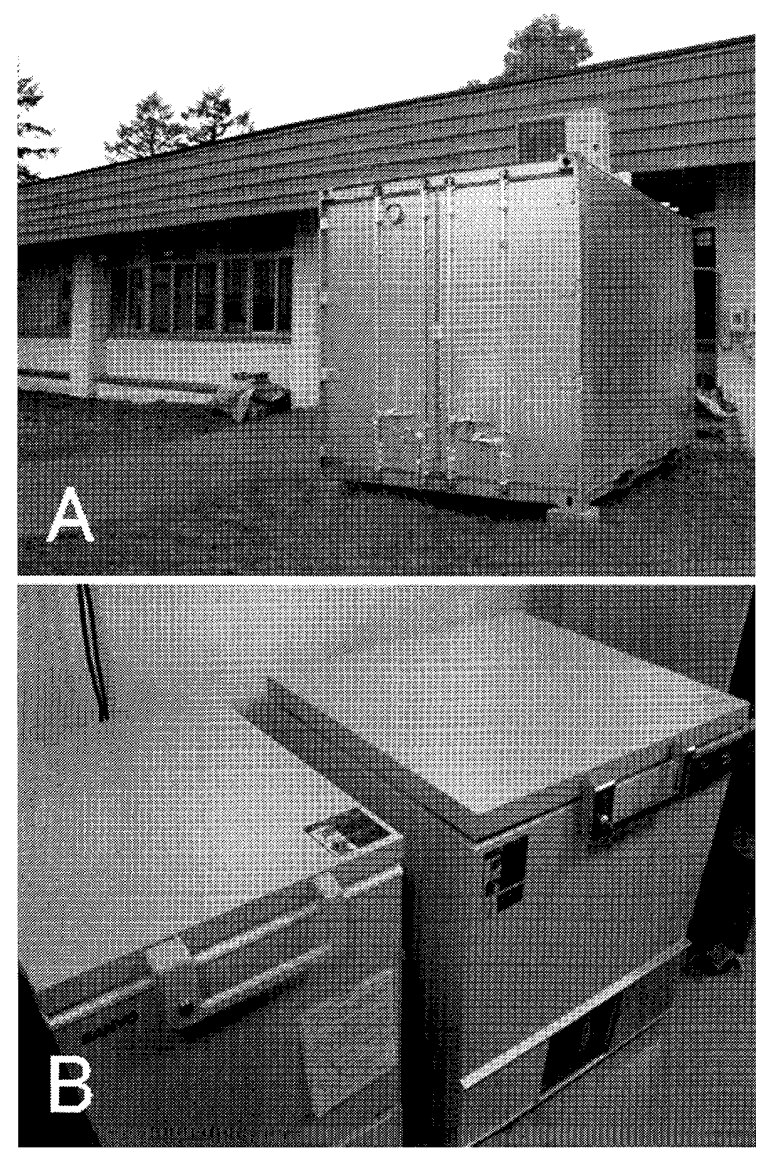

図6 带広畜産大学解剖学教室に扔ける冷凍保存設備

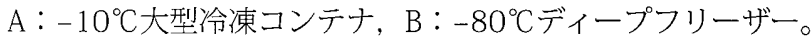

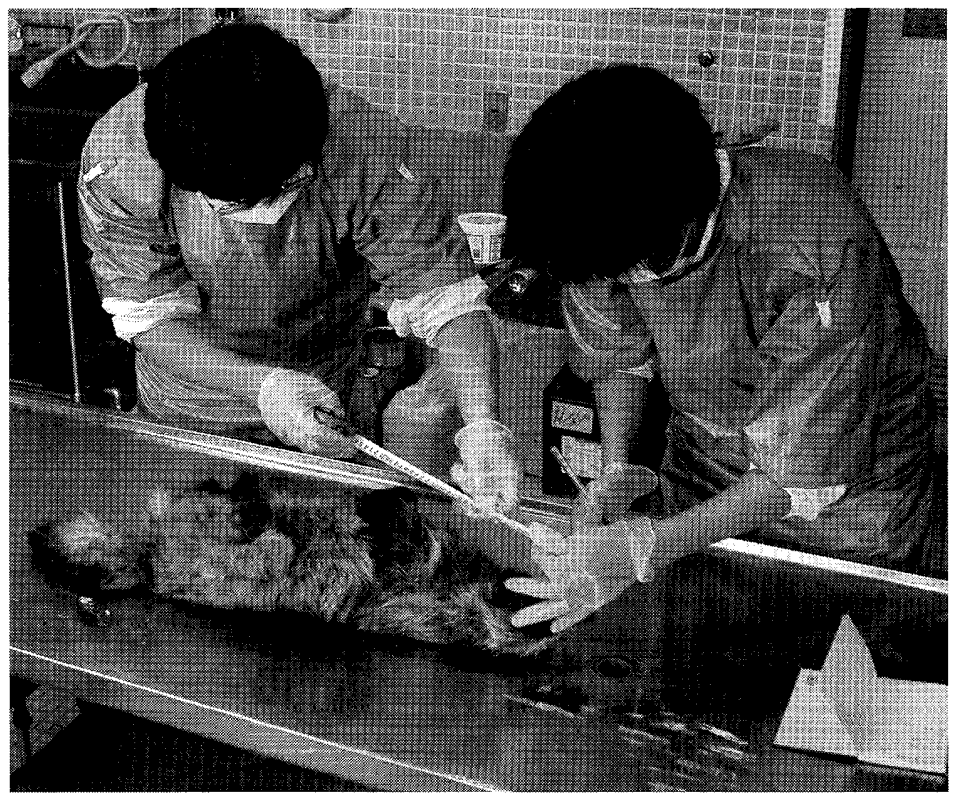

図7 超低温処理後のエゾタヌキの計測風景 
佐々木基樹
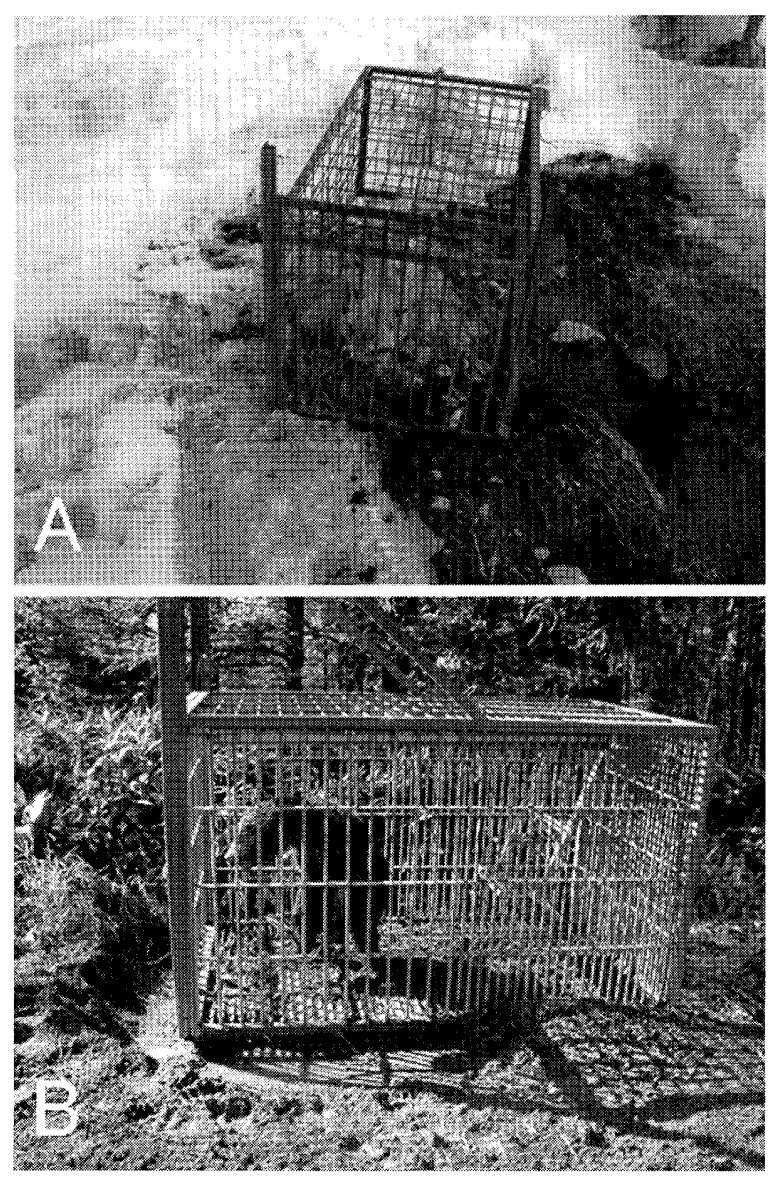

図 8 はこわなによる有害鳥獣駆除 $\mathrm{A} ：$ キタキツネ, B：ヒグマ。

シカやヒグマといった陸生動物と同様に大学に運ばれてきてお り, 解剖学教室や带広畜産大学ゼニガタアザラシ研究グループ の学生達によって体重や体長などの生物学的データが記録され ている。外部計測後に皮膚を切開して脂肪の厚さを計測し，さ らに開胸して心採血が行われている（図 10a）。一連の処理が終 了した後, 新鮮な個体で組織検索が十分可能な場合は，直ちに 解剖し臓器や器官を採材している。採材後の個体または死後時 間の経過した個体は肉眼解剖学的解析のために冷凍庫に一時保 管されている。現在, 学部生の卒業論文テーマとしてアザラシ 四肢の肉眼解剖と CT による非破壊的解析が行われている。ア ザラシの解剖時には, 特徵的な腎臓周囲の腎星状静脈叢 (renal stellate plexus) や太く薄い壁の後大静脈（caudal vena cava） などが確認された（図 10b）[33,34]。

さらに, 解剖学教室では (財) 日本鯨類研究所 (Institute of Cetacean Research）と共同研究を行っており，調查捕鯨によ って捕獲されたクロミンククジラ (Balaenoptera bonaerensis : Antarctic minke whale) から胎盤や生殖腺を採材して研究に用

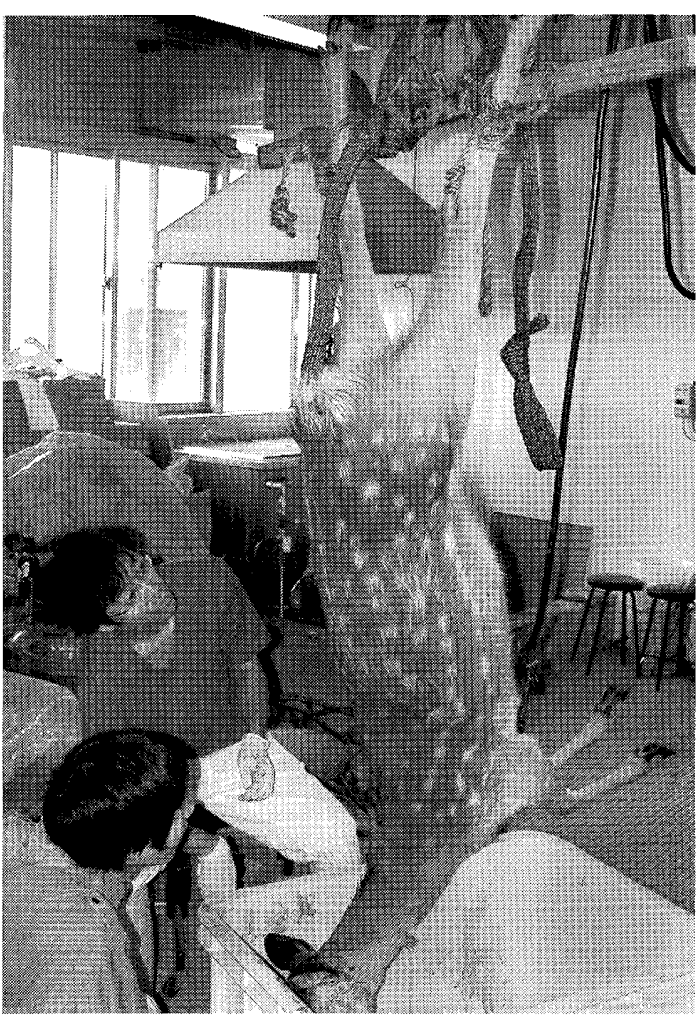

図 9 有害鳥獣駆除によるエゾシカ遺体の解剖

いている。現在, これら組織の形態および機能解析を行ってお り, 貴重な解剖学的所見が得られつつある。

次に動物園や水族館からの飼育動物遺体の利用について述べ る。解剖学教室では, 動物園や水族館から提供していただいた 飼育動物の遺体を数多く研究や教育に用いている。現在, 当教 室では, 新潟市水族館マリンピア日本海で飼育されていたフ ンボルトペンギン (Spheniscus humboldti: Humboldt penguin) の遺体を用いて, 羽の微細構造を走査型電子顕微鏡 (SEM) や 実体顕微鏡によって観察してきた。このフンボルトペンギンの 羽の構造を, しながわ水族館から提供頂く予定のイワトビペン ギン (Eudyptes chrysocome : rockhopper penguin) やマゼラン ペンギン (S. magellanicus : Magellanic penguin) の羽の構造と 比較考察していくことはとても興味深いことである。

哺乳類では，上野動物園や多摩動物園から国立科学博物館 に寄贈された遺体を利用して幾つかの研究を行ってきた。こ の研究によって, スマトラトラ (Panthera tigris sumatorae: Sumatran tiger), キリン (Giraffa camelopardalis: giraffe), ヒグマ (Ursus arctos: brown bear), ホッキョクグマ (Ursus maritimus : polar bear) の咀嚼筋構造や，モウコノウマ (Equus caballus przewalskii : Przewalski's horse) の機能形態学的特 徵, そして, ヒグマ, ホッキョクグマ, ジャイアントパンダ 


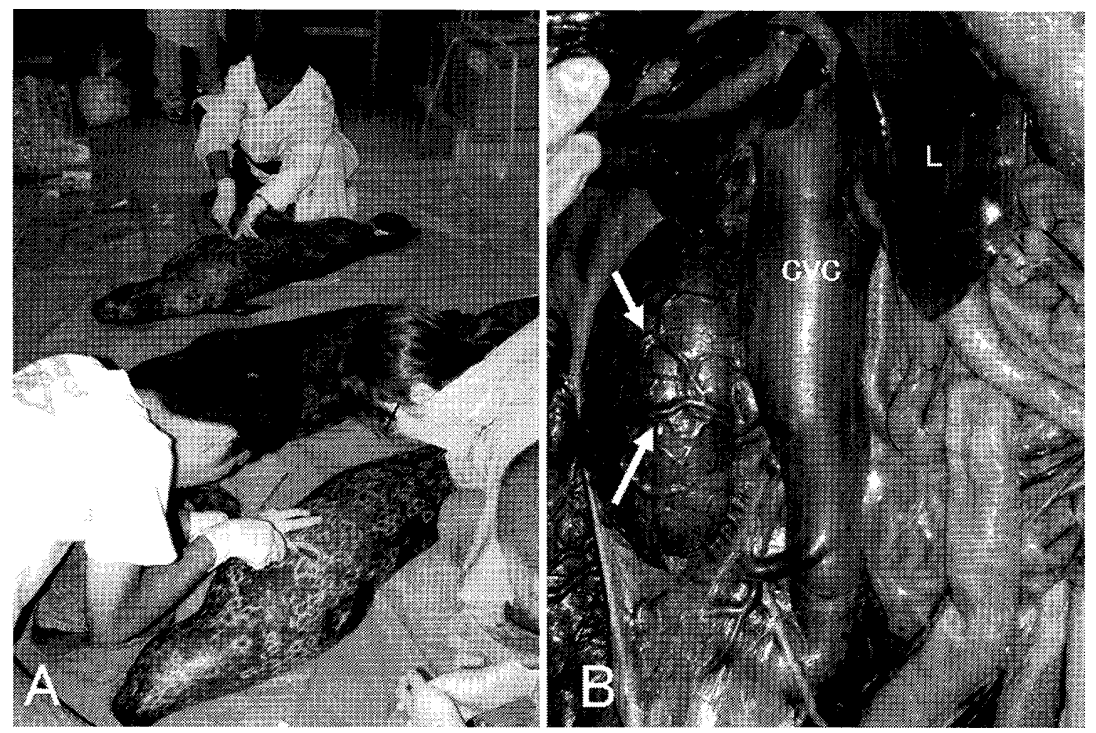

図 10 混獲によるゼニガタアザラシの遺体

$\mathrm{A}$ : 脂肪厚計測と採血風景, $\mathrm{B}$ : 腹腔内腹側観, 矢印：腎星状静脈叢（Renal stellate plexus), L : 肝臓, CVC : 後大静脈。

(Ailuropoda melanoleuca : giant panda), マレーグマ (Helarctos malayanus：Malayan sun bear）などの後肢構成筋の樹上性 適応などが明らかにされた [35-40］。さらに，旭川市旭山動 物園からは，これまでに，マルミミゾウ（Loxodonta africana cyclotis: forest elephant), キリン, ホッキョクグマ, トナカ $\checkmark$ (Rangifer tarandus : reindeer),アムールヒョウ (Panthera pardus orietalis：Amur leopard）などの飼育動物の遺体を提供 していただいている。ゾウの四肢やキリンの頭部は帯広畜産大
学付属家畜病院にて CT スキャン解析を行い, 画像を 3 次元立 体構築することで非破壞的に内部骨格構造を観察することが できた（図 11）。解析に使用する以外の部分は，煮骨し乾燥す ることによって晒骨標本を作製した（図 12）。最終的に作製さ れた骨標本は, 必要に応じて展示などが可能な状態にして保管 している（図 12C）。また, 带広畜産大学の解剖学教室と旭山 動物園では, 作製した標本を研究, 学校および社会教育に役立 てるべく現在その保管に関して柔軟に対応している。ホッキヨ

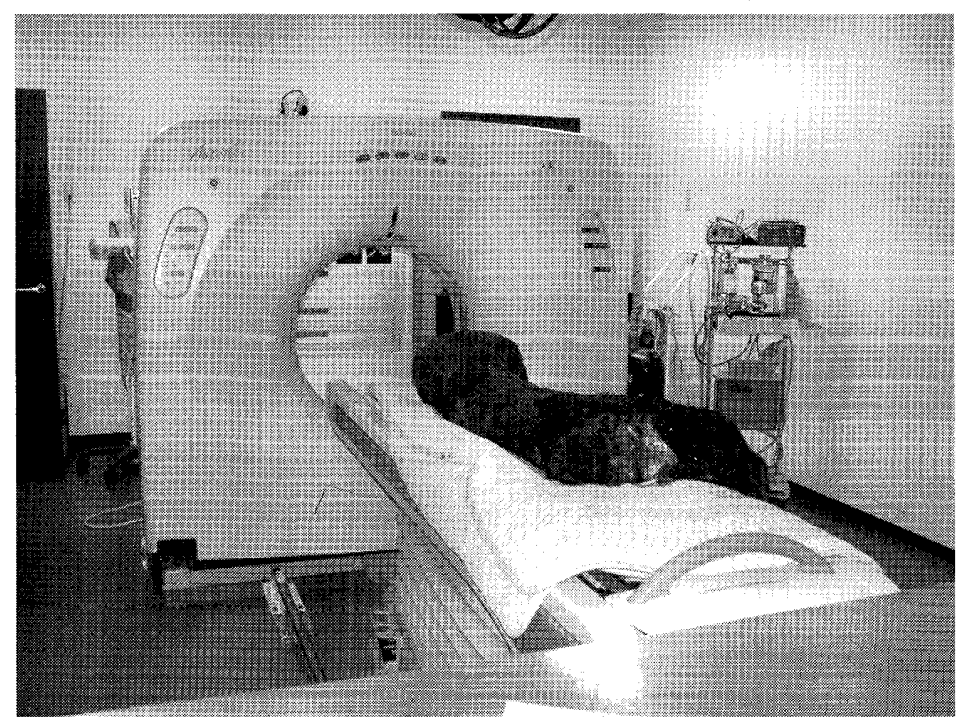

図 11 ゾウの前肢 CT 撮影風景 
佐々木基樹
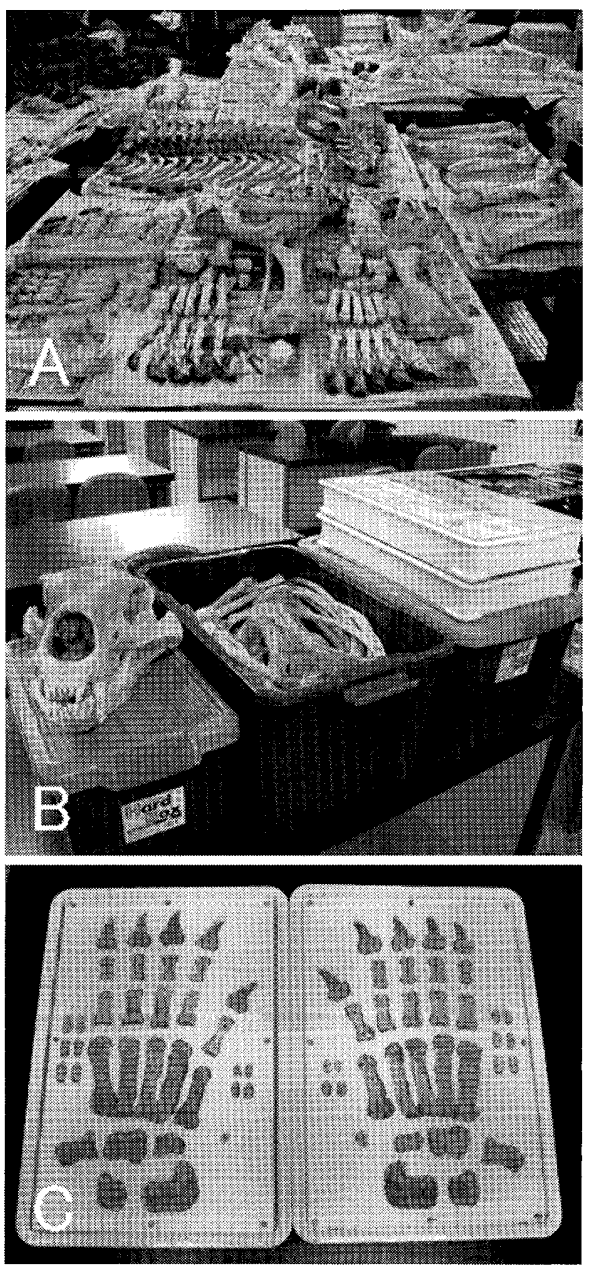

図 12 動物遺体からの骨標本作製 $\mathrm{A} ：$ 乾燥中のホッキョクグマとキリンの 骨標本, B：収納されたホッキョクグマ の骨標本, C：展示と収納を可能にした ホッキョクグマの手骨格標本。

クグマの標本は旭山動物園での社会教育に利用されるため現在 旭山動物園で保管されている（図 12B）。また，煮骨して完全 に骨標本にしてしまう前に遺体のさらなる用途をいろいろと模 索する。例えば，ゾウの前後肢の足型を石膏にて作製した（図 13）。四足動物の体重の負荷と足の大きさの違いを理解するた めの社会教育的教材としては十分に利用価值があるのではと 考えている。これも先のホッキョクグマの骨標本と同様に旭山 動物園の方に保管されている。また，大学と同じ市内にある帯 広動物園からもシベリアヘラジカ (Alces alces: Eurasian elk), カバ (Hippopotamus amphibius: Hippopotamus), フタコブラ クダ (Camelus bactrianus: two-humped camel) といった動物 の遺体を提供していただいて㘧り，これら遺体からも貴重な研
究成果が得られつつある。

\section{獣医学から野生動物医学へ}

帯広畜産大学の獣医学科では, 獣医解剖学と同実習が 2 年 次に開講されている。このときに初めて家畜の筋, 骨格そし て臓器の形態や位置を詳細に学ぶことになる（図 14）。しかし, 哺乳類に関して言えば，地球上に生息する約 4,500 種のうち 家畜化された数種の動物を対象にするだけで, 鳥類に至って はほぼ家禽だけが対象となっている。しかし, 動物園や水族館 に多くの野生動物が飼育されている現状を考えれば, 獣医解剖 学教育の中に野生動物（家畜の枠を越えた比較解剖学）や系統 解剖学の内容を積極的に加えていく必要があると考える。例え ば，ネコの上腕骨には，上腕動脈と正中神経が通過する顆上孔 (Supracondylar foramen) という孔が存在する [11]。家畜の中 ではこの顆上孔を持つ動物はネコだけであるが, 実際には他の ネコ科動物, カンガルーなどの有袋類, アルマジロ, アリクイ, アザラシ，マングースなど多くの動物種に存在している（図 15)。また，陰茎骨という陰茎内に生じる骨が存在しているが, 日本の獣医学教育ではその骨を所有する動物をイヌ，良くて食 肉類としか教えないであろう。しかし, リスなどのげっ歯類, ヒトを除く霊長類, そして翼手類など多くの哺乳類がこの陰萃 骨を保有しており, 種の同定にもこの骨は用いられている（図 16) $[41,42]$ 。

大学での獣医学教育において, 解剖学を例にすれば家畜での 形態学的知識をより多くの動物へとその対象を広げていく機会 をつくることは野生動物医学の充実, さらに広い視野と豊富な 知識をもった獣医師の育成にとって必要不可欠なことだと考え る。このことは解剖学だけではなく多くの分野にも共通するこ とではないだろうか。

\section{動物遺体の有効利用}

動物に命の限りがある以上必ず遺体は生じてくる。遺体やそ れから作製された標本には数多くの情報が眠っており，またそ れらには多くの利用価值が存在している。遺体から多くの情報 を引き出し，そして，その遺体自身を状況に合わせてさまざ まな形で残すことでその利用価值を最大限発揮させていくこと は, 実際は想像以上に大変なことである。昨今の合理化と成果 主義的社会風潮に, 我が国の研究者や教育者（学校教育, 社会 教育に従事する者）に余裕がなくなっているのも事実である。 しかし, そのような逆境の中, 一人ひとりの努力によって動物 遺体が社会教育, 学校教育, そして研究へと数々の用途に無駄 なく利用されていく環境が整っていけば，それはまさに理想的 なことである（図 17）。また, 動物遺体やそこから生まれる二 次的な産物が, 動物園・水族館, 博物館, そして大学を含めた 

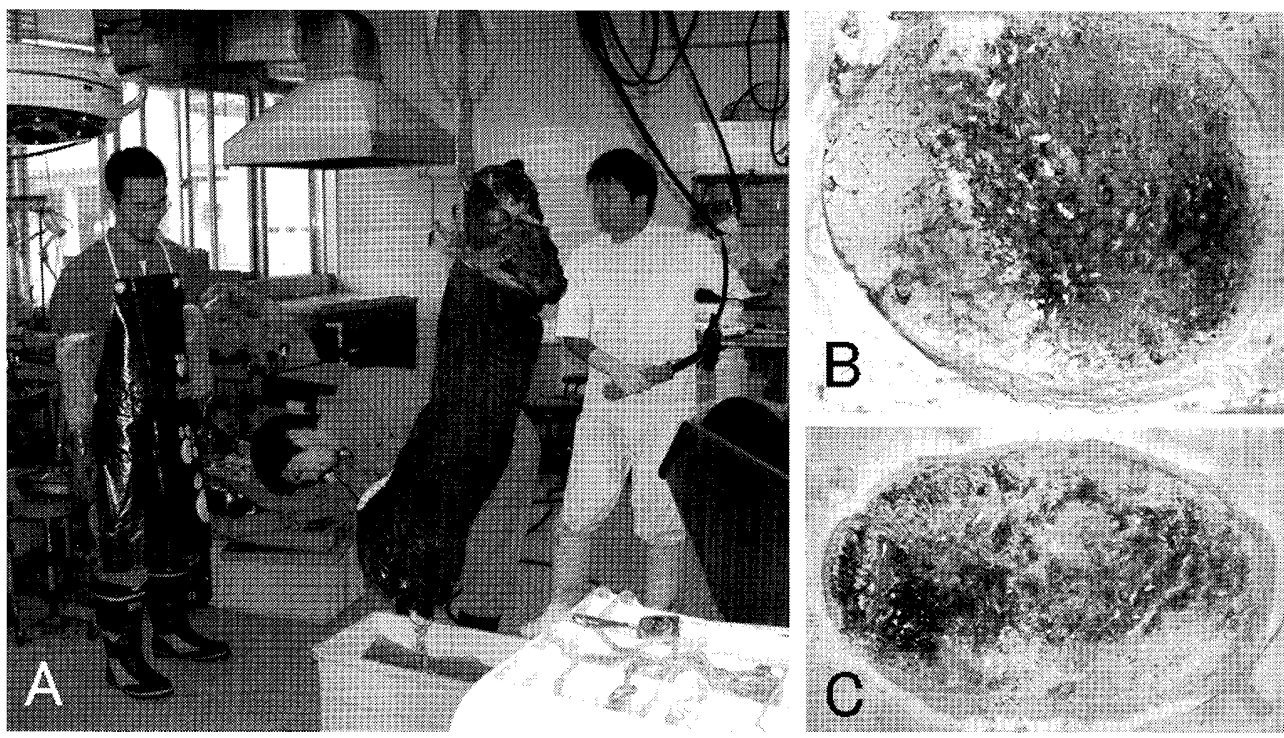

図 13 ゾウの足型作製

$A$ ：足型作製風景， $\mathrm{B}$ ：右前肢石膏足型， $\mathrm{C}$ ：右後肢石膏足型。
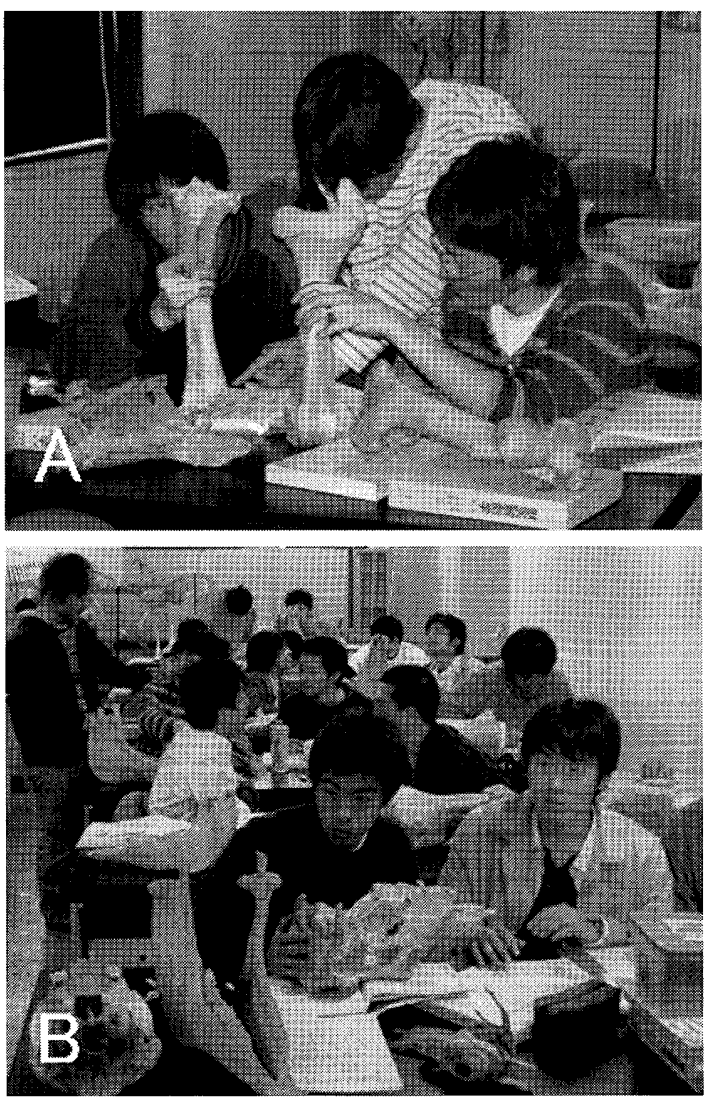

図 14 帯広畜産大学獣医学科 2 年次での獣医解 剖学実習風景

A：後肢骨の骨学実習，B：頭蓋の骨学実習。
研究機関の間で，一方的な依存関係ではなく相互に遺体のもつ 価值を共有できるような関係を構築していくことは重要なこと であると考える（図 18）。

\section{謝 辞}

本稿で紹介致しました教育や研究に使用した動物遺体または 標本をご提供いただきました, 旭山動物園, 上野動物園, 帯広 動物園, 多摩動物公園, しながわ水族館, 新潟市水族館, 広尾 海洋水族科学館, 国立科学博物館, (財) 日本鯨類研究所, 京 都大学霊長類研究所, 北海道猟友会 (興部支部: 西興部部会, 興部部会, 帯広支部: 帯広部会, 中札内部会), エゾシ力協会, 西興部村養鹿研究会, 西興部村猟区管理協会に心より感謝致し ます。また，実際に遺体提供の対応やさまざまな御助言をいた だきました, 小菅正夫園長, 坂東元副園長, 福井大祐先生, 中 村亮平先生 (旭山動物園), 増井光子園長 (兵庫県立コウノトリ の郷公園/よこはま動物園ズーラシア), 成島悦雄先生 (多摩動 物公園), 進藤順治先生 (新潟市水族館), 藤本智先生, 小林伸 行先生 (带広動物園), 徳山秀雄館長 (広尾海洋水族科学館), 荒 幡経夫館長, 山田仁氏, 長塚信幸先生 (しながわ水族館), 遠藤 智子先生 (サンシャイン国際水族館), 大隅清治先生, 石川創先 生, 茂越敏弘先生 ((財) 日本鯨類研究所), 遠藤秀紀先生 (京 都大学霊長類研究所), 梶光一先生 (東京農工大学), 近藤誠司 先生, 鈴木正嗣先生 (北海道大学), 坪田敏男先生 (岐阜大学), 木村順平先生, 村田浩一先生 (日本大学), 川田伸一郎先生（国 立科学博物館), 中原慎一氏 (西興部村養鹿研究会), 伊吾田宏正 

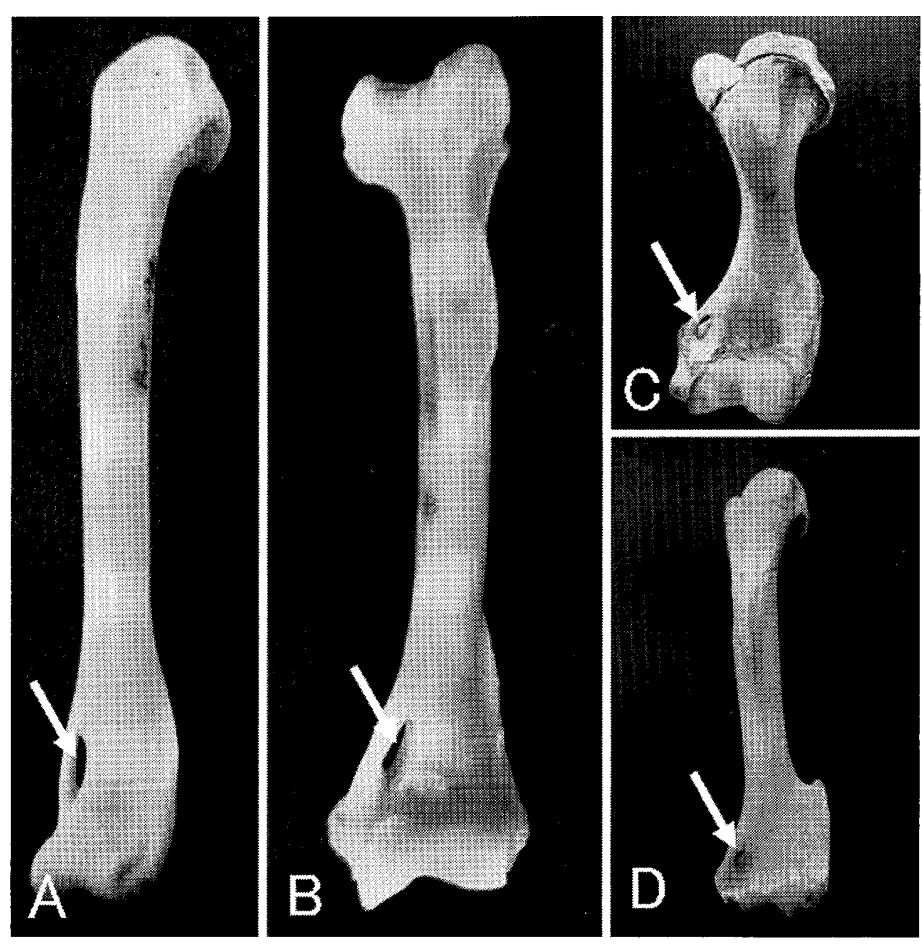

図 15 顆上孔を持つ動物の左上腕骨 $\mathrm{A}$ ：ネコ, B：ヒョウ, C：ゼニガタアザラシ, D：フ クロギツネ(有袋類)（国立科学博物館収蔵標本）。 矢印：顆上孔，全て頭側観。
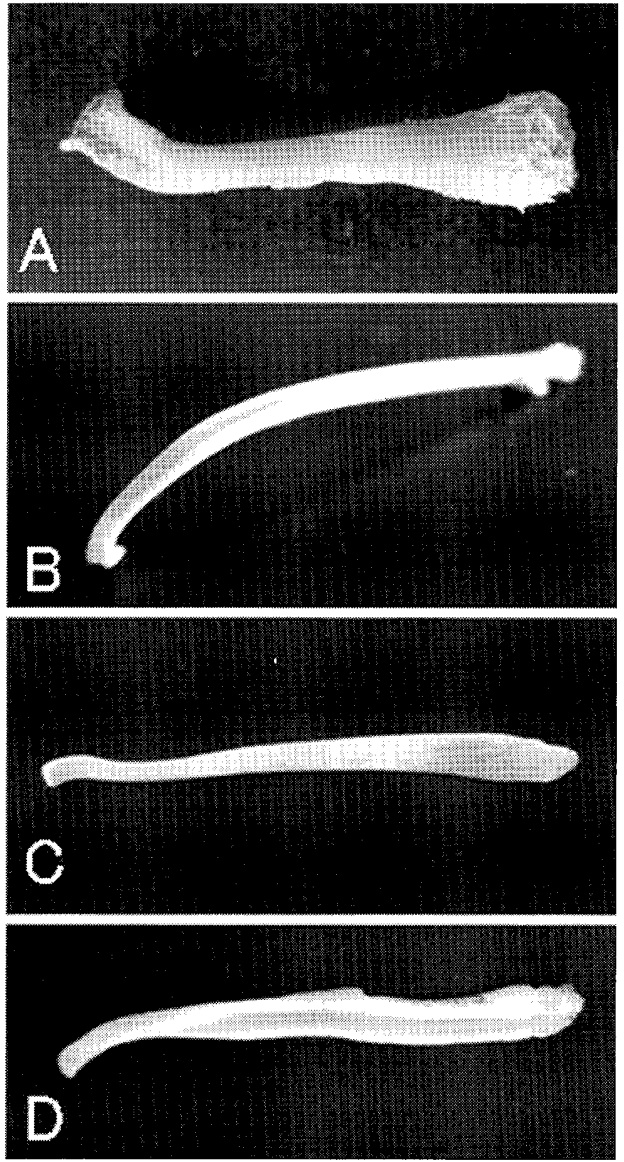

図 16 陰茎骨

$\mathrm{A}$ ：ムササビ， B：ミンク，C：ホッキョクグマ（旭 山動物園収蔵標本), D：イヌ。 


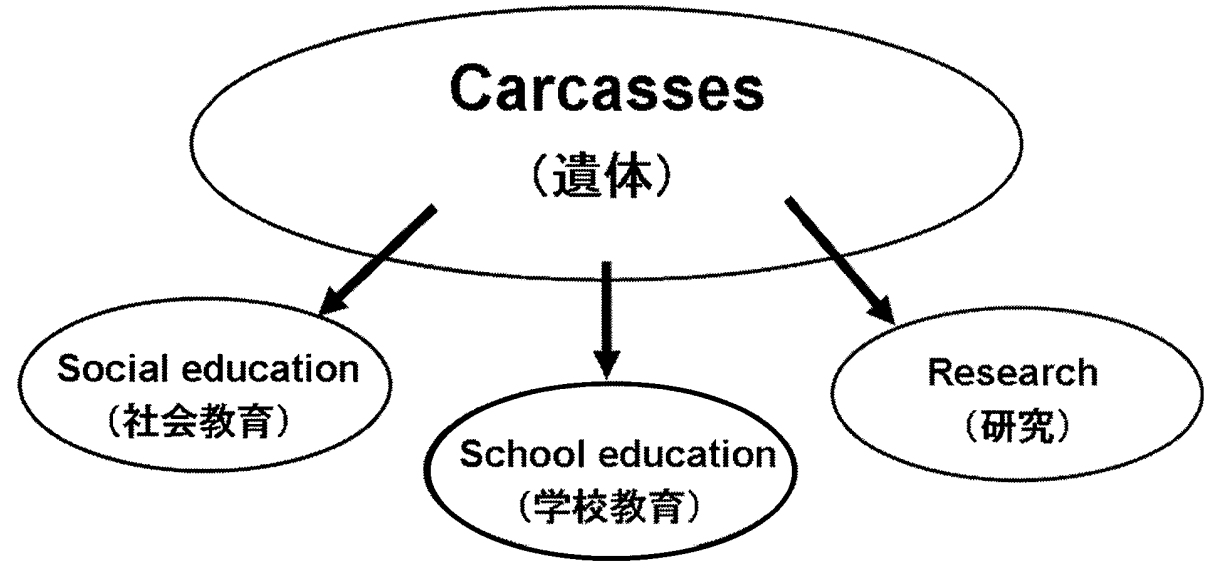

図 17 動物遺体の利用目的

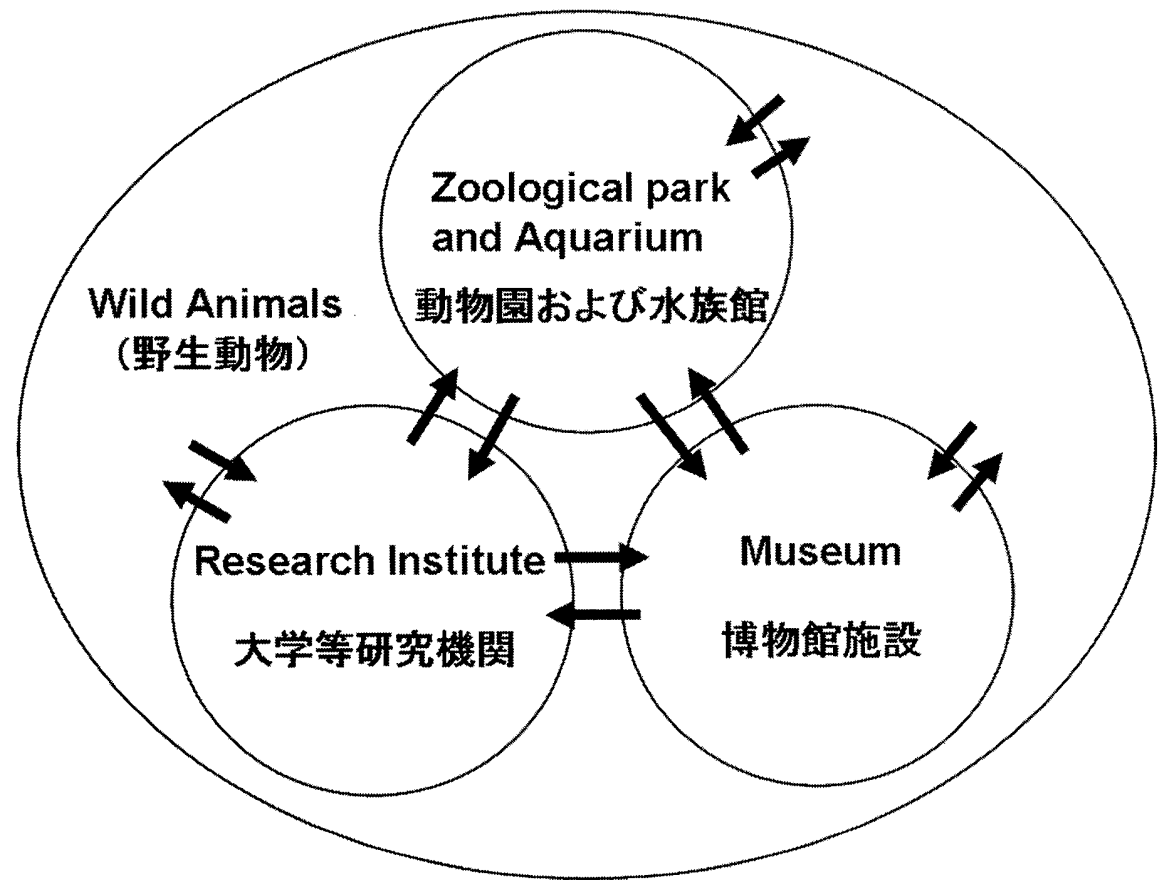

図 18 動物遺体利用の相互依存

氏 (西興部村猟区管理協会), 福井豊先生, 宮本明夫先生, 手塚 雅文先生, 柳川久先生, 押田龍夫先生 (帯広畜産大学), 山田純 三先生 (帯広畜産大学名誉教授)には心より深謝致します。さ らに, 帯広畜産大学放射線学教室の山田一孝先生には数々の遺 体のX 線 CT 撮影を行っていただき, また, 同大学病理学教室 の古林与志安先生にはことあるごとに遺体の病理診断をして頂 きました。この場をお借りして心より扎礼申し上げます。さら に, 帯広畜産大学解剖学教室の北村延夫教授には日々多くの助
言をいただき,また，同大学解剖学教室の所属学生および帯広 畜産大学ゼニガタアザラシ研究グループの所属学生には遺体の 解剖で大変にお世話になりました。心より感謝致します。

本稿に記載した研究の一部は, 文部科学省科学研究費助成 (No. 17405018，17770064，18405034，18405036）, 文 部科学省 21 世紀 COE プログラム研究助成 (E-1), そして独立 行政法人日本学術振興会先端研究拠点事業 HOPE の助成によ つて行われた。 


\section{佐々木基樹}

\section{要 約}

動物の遺体は，さまざまな経路によって帯広畜産大学解剖学 教室に集められ，そして研究や教育に用いられている。野生動 物の遺体の収集は, A：死因不明の野生下死亡個体，B：交通 事故個体, $\mathrm{C}$ : 狩編, 有害鳥獣駆除, 学術調查捕獲, 混獲とい つた捕獲個体，そして，D：動物園や水族館から提供して頂く 死亡飼育動物，が対象となる。これら野生動物の遺体から得ら れたデータや遺体から作製された標本は，野生動物医学の充実 と多様な知識をもった獣医師育成のためにも獣医学教育に積極 的に取り入れる必要性があると考える。また，動物遺体が社会 教育, 学校教育, そして研究へと幅広い用途において利用され, さらに，これら遺体が教育機関や研究機関の間で相互依存的に 有用活用されていくことが望まれる。

キーワード：動物遺体，解剖学，社会教育，学校教育

\section{引用文献}

1. Owen R. 1866. On the Anatomy of Vertebrates, vol.1, Longmans, Green \& Co., London.

2. Gegenbaur C. 1898. Vergleichende Anatomie der Wirbelthiere mit Ber ücksichtung der Wirbellosen, Band 1. Verlag von Wilhelm Engelmann, Leipzig.

3. Bolk L, Göppert E, Kallius E, Lubosch W. 1967. Handbush Vergleichenden Anatomie der Wirbeltiere. A. Asher \& Co, Amsterdam

4. Portmann A. 1969. Einführung in die Vergleichende Morphologie der Wirbeltiere. 脊椎動物比較形態学 (島崎三郎訳), 1979. 岩波書店, 東京.

5. Grassé, PP ed. 1971. Traité de Zoologie, Anatomie, Systématique, Biologie, TOME X VI . Masson et $\mathrm{C}^{\mathrm{le}}$, Paris.

6. Romer AS, Parsons TS. 1977. The Vertebral Body. 9th ed. W.B. Saunders, Philadelphia.

7. Stevens CE, Hume ID. 1995. Comparative Physiology of the Vertebrate Digestive System, 2nd ed. Cambridge University Press, Cambridge.

8. Kent GC, Carr RK. 2001. Comparative Anatomy of the Vertebrates. 9th ed McGraw-Hill Higher Education, NY

9. Kardong V. 2002. Vertebrates. Comparative Anatomy, Function, Evolution. 3rd ed. McGraw-Hill Higher Education, NY.

10. 倉谷滋. 2004. 動物進化形態学. 東京大学出版会, 東京.

11. Crouch JE. 1969. Text-atlas of Cat Anatomy. LEA\&FEBIGER, Philadelphia.

12. Getty, R. 1975. Sisson and Grossman's the Anatomy of the Domestic Animals, Vol.1, 5th ed. W.B Saunders Company, Philadelphia, London and Tronto.

13. Barone R, Pavaux C, Blin PC, Cuq P. 1973. Atlas D'Anatomie du Lapin 息の解剖図譜 (望月公子訳), 1977. 学空社, 東京.

14. Getty, R. 1975. Sisson and Grossman's the Anatomy of the Domestic Animals, Vol.2, 5th ed. W.B Saunders Company, Philadelphia, London and Tronto.

15. Ellenberger W, Baum H. 1977. Handbuch der Vergleichenden Anatomie der Haustiere, 18 Auflage. Springer-Verlag, Berlin, Heidelberg, NY.
16. Shummer A, Nickel R. 1979. The Viscera of the Domestic Mammals, Vol.2. Verlag Paul Parey, Berlin and Hamburg.

17. Shummer A, Wilkens H, Vollmerhaus B, Habermehl KH. 1981. The Anatomy of the Domestic Animals. Vol.3. Verlag Paul Parey, Berlin and Hamburg.

18. Nickel R, Shummer A, Seiferle E, Wilkens H, Wille KH, Frewein J. 1986. The Anatomy of the Domestic Animals. Vol.1. Verlag Paul Parey, Berlin and Hamburg.

19. Dyce KM, Sack WO, Wensing CJG. 1987. Textbook of Veterinary Anatomy. W.B. Saunders, Philadelphia.

20. Popesko P, Rajtova V, Horak J. 1992. A Colour Atlas of Anatomy of Small Laboratory Animals, Vol. 1; Rabbit • Guinea pig. Wolfe Publishing Ltd., London.

21. Popesko P, Rajtova V, Horak J. 1992. A Colour Atlas of Anatomy of Smail Laboratory Animals, Vol. 2, Rat • Mouse - Hamster. Wolfe Publishing Ltd., London.

22. Schaller O. 1992. Illustrated Veterinary Anatomical Nomenclature. Ferdinand Enke Verlag, Stuttgart.

23. Evans HE. 1993. Miller's Anatomy of the Dog, 3rd ed. W.B. Saunders, Philadelphia.

24. Yasuda M. 2002. The Anatomical Atlas of Gallus. University of Tokyo Press, Tokyo

25. 加藤嘉太郎, 山内昭二. 2003. 新編, 家畜比較解剖図説上巻. 東京, 養 賢堂

26. 加藤嘉太郎, 山内昭二. 2003. 新編, 家畜比較解剖図説 下巻. 東京, 養 賢堂

27. Hoffmann CK, Weyenbergh Jr H. 1870. Die Osteologie und Myologie von Scirus Vulgaris $L$. Loosjes Erben, Haarlem.

28. Davis DD. 1964. The Giant Panda; A Morphological Study of Evolutionary Mechanisms. Fieldiana Zoology Memory Vol.3. Chicago natural history museum, Chicago.

29. Greene EC. 1935. Anatomy of the Rat, ラットの解剖図譜（望月公子監 修), 1983. 学空社. 東京.

30. Smuts MMS, Bezuidenhout AJ. 1987. Anatomy of the Dromedary. Oxford University Press, Oxford.

31. 山下次郎, 神谷正男. 1997. 增補版エ中ノコックス, その正体と対策。 北海道大学図書刊行会, 札幌

32. 淺野 玄, 塚田英晴, 岸田真弓. 2006. 生体捕獲調查に打引る計測, 採材, 器具装着扔よび衛生上の諸注意. 哺乳類科学 46 (1) : 111-131

33. King JE. 1983. Seals of the World. 2nd ed. Cornell University Press, NY.

34. Berta A, Sumich J. 1999. Marine Mammals, Evolutionary Biology. Academic Press, California.

35. Sasaki M, Endo H, Yamagiwa D, Yamamoto M, Arishima K, Hayashi Y. 1999. Morphological character of the shoulder and leg skeleton in Przewalski's horse (Equus przewalskii). Ann. Anat. 181: 403-407.

36. Sasaki M., Hayashi Y, Koie H, Yamaya Y, Kimura J. Manglai D, Kawashima S, Endo H, Yamamoto M. 1999. CT examination of the Guttural Pouch (Auditory Tube Diverticulum) in Przewalski's horse (Equus przewalskii). J. Vet. Med. Sci. 61 (9) : 1019-1022.

37. Sasaki M, Endo H, Yamamoto M, Arishima K, Hayashi Y. 2000. The superficial layer of the Musclus masseter and the well- developed process 


\section{動物の遺体をいかに解剖するか}

of the maxilla in the tiger Panthera tigris. Mammal Study 25: 27-34.

38. Sasaki M, Yamagiwa D, Takagi H, Endo H, Arishima K, Makita T, Hayashi Y. 2000. Adaptation of the muscles of mastication to flat skull feature in the polar bear (Ursus maritimus). J. Vet. Med. Sci. 62: 7-14.

39. Sasaki M, Endo H, Kogiku H, Kitamura N. Yamamoto M, Arishima K, Yamada J, Hayashi Y. 2001. The tructure of the Masseter Muscle in the Giraffe (Giraffa camelopardalis), Anat. Histol. Embryol. 30: 313-319.

40. Sasaki M, Endo H, Wiig Ø, Derocher AE, Tsubota T, Taru H, Yamamoto M,
Arishima, K, Hayashi Y, Kitamura N, Yamada J. 2005. Adaptation of the hindlimbs for climbing in bears. Ann. Anat.187: 153-160.

41. Vaughan TA, Ryan JM, Czaplewski NJ. 1999. Mammalogy. 4th ed. Brooks/Cole Pub Co, Ca.

42. Good JM, Demboski JR, Nagorsen DW, J. 2003. Phylogeography and introgressive hybridization: chipmunks (Genus Tamias) in the northern rocky mountains. Evolution 57: 1900-1916. 